\title{
ALTERNATIVE LUBRICANTS: STUDY ON PALM OIL-BASED LUBRICANTS IN METAL FORMING PROCESS
}

\author{
M A NURUL*; S SYAHRULLAIL* and TENG, H W*
}

\begin{abstract}
Mineral oil-based lubricants are always the preferred choice for industrial application due to their excellent properties and reasonable price. However, due to environmental and depletion issues, a number of studies have been carried out to explore alternative lubricants such as plant oils. In metal forming processes, reducing frictions, improving tool life and product quality are some of the important issues to be considered. In our study, palm oil-based lubricants were tested for cold extrusion processes and mineral oils were used for comparison purposes. It was found that refined bleached deodorised (RBD) palm kernel oil and palm olein performed an enhanced extrusion load than mineral oil-based lubricant, and they showed no severe wear on product surface. Based on the results, renewable oil-based lubricants can be considered as a substitute to common mineral oil based lubricants used in the industry.
\end{abstract}

Keywords: mineral oil-based lubricants, palm oil-based lubricants, viscosity, cold extrusion process.

Date received: 15 June 2015; Sent for revision: 29 July 2015; Received in final form: 9 November 2015; Accepted: 13 January 2016.

\section{INTRODUCTION}

Metal forming processes are the manufacturing processes that plastically deform a metal into desired shape. The different types of metal forming processes available in the industry are metal casting, metal rolling, metal forging, metal extrusion, metal drawing, sheet metal and other manufacturing processes. For most manufacturing processes, lubricant is used to reduce friction of the surfaces between work piece and tool as well as to protect the tool from wear.

Lubrication is widely used by the industry to separate work piece and tool surfaces, hence, reducing interface friction as well as to ease metal flow in order to produce high quality products and increase tool life (Hu and Dean, 2000). The types of

\footnotetext{
* Faculty of Mechanical Engineering,

Universiti Teknologi Malaysia,

81310 UTM Skudai, Johor, Malaysia.

E-mail: m.a.nurulaini@gmail.com
}

lubricants preferred by the industry are mineralbased lubricants (Andreas, 2001). The good technical properties and acceptable price of the mineral oils are some of the reasons why mineral oil-based lubricants are preferred by the industries.

Resource depletion, as far as the consumption of mineral oil is concerned, has emerged as one of the world environmental concerns (Gariety et al., 2007). Looking at it as a global issue, researchers from all over the world have explored and looked for other alternatives to substitute these non-renewable lubricants. As renewable oil, vegetable oils such as palm oil, jatropa oil, corn oil, and sunflower oil have been widely explored.

Palm oil industry is one of Malaysia's biggest achievements because it is able to transform the economic growth, from main commodity production country with agricultural basis to modern production country for value-added food products (MPOB, 2014).

A number of research have been done in order to explore the possibility of replacing the use of 
mineral oils as lubricants in the industry. Caminaga et al. $(2006 ; 2007)$ experimenting on various types of potential lubricants reported that surface roughness and dimensional quality of products extruded with these alternative lubricants were similar to those found in the cold extrusion tests. Lovell et al. (2006) discovered that boric acid and canola oil lubricants have substantial potential to be used by the manufacturing community as commercially viable and environmental-friendly alternatives that will allow the forming of complex parts.

Wheat flour lubricant was explored by Hirofumi et al. (2002) to develop a non-polluting lubricant for the sheet metal-forming process. As expected, the sheet coated with wheat flour had a higher formability than the sheet coated with press oil.

The introduction of environmental legislation series by Occupational Safety and Health Act (OSHA) and other international regulation authorities, has forced the manufacturing sector to reduce the consumption of mineral oil-based metal working fluids. There is a huge potential for utilising vegetable oils as cutting fluids in the manufacturing sector, as shown in Table 1. For example, palm oil is still preferred as a lubricant for cold rolling.

Since 1939, various types of vegetable oil including palm oil were used as lubricant. Some of the commonly used vegetable oils is listed in Table 2. Unfortunately, they are limited by their poor low temperature fluidity and poor oxidative stability at high temperatures. The most desirable oil for lubricant is oil with a high percentage of monosaturated fatty acid, moderate amount of polyunsaturated fatty acid and low amount of polyunsaturated fatty acid and saturated fatty acid.

The formation of mineral oil requires millions of years, under the condition of high pressure and temperature. Therefore, it is impossible to replenish it at the same rate as it is being used up. Besides, as the amount of mineral oil supply is getting lesser, there is no guarantee that the mineral oil will be available in the future. In addition, the price of mineral oil is expected to increase dramatically as the supply is getting lower in the future (Quinchia et al., 2014). Therefore, the application of plant oil to replace mineral oil is considered a new alternative. The amphiphilic properties enable vegetable oil to have better lubricity and therefore more effective than mineral oil as a lubricant (Serope and Steven, 2010). Besides, stable and limited range of viscosities also makes vegetable oil suitable lubricant in many metal forming operations.

This study was conducted to explore the possibility of having palm oil-based lubricant as the alternative to mineral-based lubricant, by considering a few aspects to the extrusion product including extrusion load, surface roughness and velocity. Palm oil, or so called as plant oil is chosen because it possesses some characteristics which make it suitable to be used as a lubricant in extrusion. Besides that, palm oil is a renewable resource and environmental-friendly, so that it can be easily decomposed. As a result, the cost of acquiring plant oil is much cheaper, compared to mineral and synthetic oil. Thus, the usage can help to overcome the issues of environmental pollution. As Malaysia is one of the largest producers of palm oil in the world, and palm oil production is vital for Malaysian economy, exploration of its new potential application is necessary and demands further attention. Hopefully, this study would help to promote more application of renewable natural resources as well as to protect the environment.

\section{MATERIALS AND METHODS}

Figure 1 shows a schematic sketch of cold work, vertical, forward extrusion process used in the experiment. The main components are container, taper die and billet. The die half angle of the taper die used is $45^{\circ}$. The taper die is made of tooled

TABLE 1. ADVANTAGES AND DISADVANTAGES OF VEGETABLE OILS AS LUBRICANTS

\begin{tabular}{ll}
\hline \multicolumn{1}{c}{ Advantages } & \multicolumn{1}{c}{ Disadvantages } \\
\hline Required qualities of metal working fluids & Low thermal stability \\
High biodegradability & Oxidative stability \\
Low pollution of the environment & High freezing points \\
Compatibility with additives & Poor corrosion protection \\
Low production cost & \\
Wide production possibilities & \\
Low toxicity & \\
High flash points & \\
Low volatility & \\
High viscosity indices
\end{tabular}

Source: Babatunde and Michael (2008). 
TABLE 2. POTENTIAL APPLICATIONS FOR VARIOUS VEGETABLE OILS

\begin{tabular}{ll}
\hline Vegetable/animal oil & \multicolumn{1}{c}{ Common application } \\
\hline Olive oil & Automotive lubricants \\
Sperm oil & $\begin{array}{l}\text { Spindle lubricant in textile mills, automotive transmission } \\
\text { fluids, metal cutting fluids, instrument oils }\end{array}$ \\
Rapessed oil & $\begin{array}{l}\text { Metal forming processes. Chain saw bar lubricants, air } \\
\text { compressor-farm equipment, biodegradable greases }\end{array}$ \\
Castor oil & Gear lubricants \\
Coconut oil & Used for compounding gas and petrol engine oils \\
Palm oil & Used for steel industry for rolling thin gauge strip, railway \\
& wagon greases \\
Tallow & Used for compounding steam cylinder oils \\
Canola oil & $\begin{array}{l}\text { Hydraulic oils, tractor transmission fluids, metal working } \\
\text { fluids, food grade lubes, penetrating oils, chain bar lubes }\end{array}$ \\
\hline
\end{tabular}

Source: Babatunde and Michael (2008).

steel (SKD11), and necessary heat treatments were performed before the experiment. The experimental surfaces of taper dies (surface in contact with the billet) were polished with abrasive paper. A surface roughness $R a$ of approximately $0.15 \mu \mathrm{m}$ was recorded.

This experiment was carried out with the laboratory press machine at room temperature. This plain extrusion apparatus was assembled and placed on the load cell to record the load extrusion (y-axis) during each test. The displacement of ram stroke (x-axis) was also recorded by using the displacement sensor, which was attached to the holder of the plain extrusion apparatus. Extrusion was stopped at a piston stroke of $35 \mathrm{~mm}$, where the extrusion process was expected to reach a steady state. The ram speed was constant at $7.6 \mathrm{~mm} \mathrm{~s}^{-1}$. Lubricant was applied onto the taper die (surface which has contact with

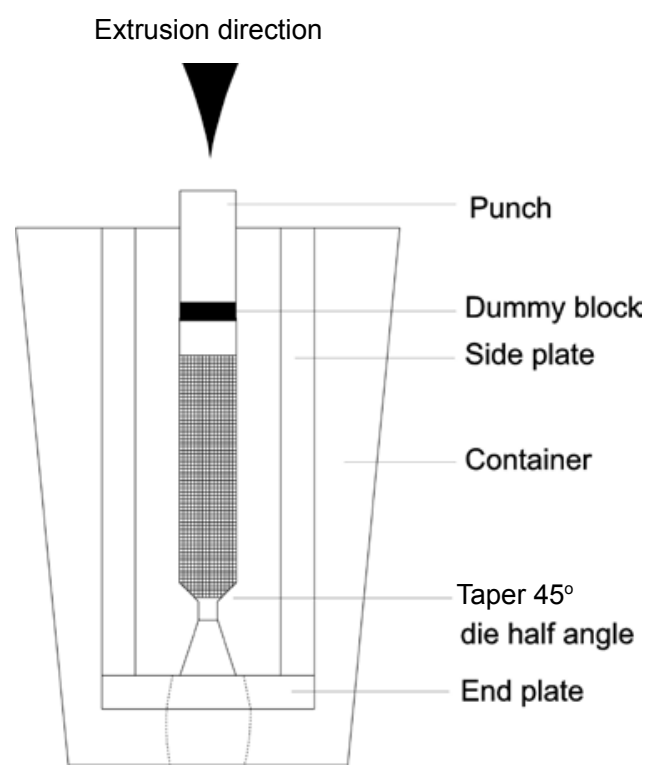

Figure 1. Schematic sketch of cold work extrusion process. the billet) before the test. The billets were cleaned using acetone. During the extrusion process, the two similar billets were stacked and used as one unit of billet was fixed on a container and extruded through a pair of taper dies. After the experiment, the partially extruded billets were taken out from the plane extrusion apparatus and surface roughness of the billet with the observation plane was measured. Then, the extrusion load was analysed.

Figure 2 shows a schematic sketch of the billets used in the experiment. The billet material is pure aluminum (A1100). The billets' shapes were formed by a numerical control (NC) wire cut electric discharge machining device. One side of the contact surface of the combined billets was the observation plane of plastic flow in plane strain extrusion. The observation plane was not affected by the frictional constraint of the parallel side walls. A square grid pattern measuring the material flow in the extrusion process was scribed by the NC milling machine on the observation plane of the billet. The grid lines were V-shaped grooves with $0.5 \mathrm{~mm}$ depth, $0.2 \mathrm{~mm}$ width, and $1.0 \mathrm{~mm}$ interval length. The billets were annealed before the experiment. The annealed condition is the best for cold forming due to the ferrite, which is present in its microstructure (Janosec et al., 2007).

\section{Lubricants}

The objective of this research was to explore the possibility of using plant oil as a substitute for industrial oil in the extrusion process. The lubricants used in this study were refined, bleached, deodorised (RBD) palm olein and RBD palm kernel oil, while mineral oils used for comparison purposes were mineral oil VG95 and daphnee. RBD means that the oil has gone through a purifying process to remove the unwanted free fatty acid and odour. A fractionation process involves a physical process of cooling 


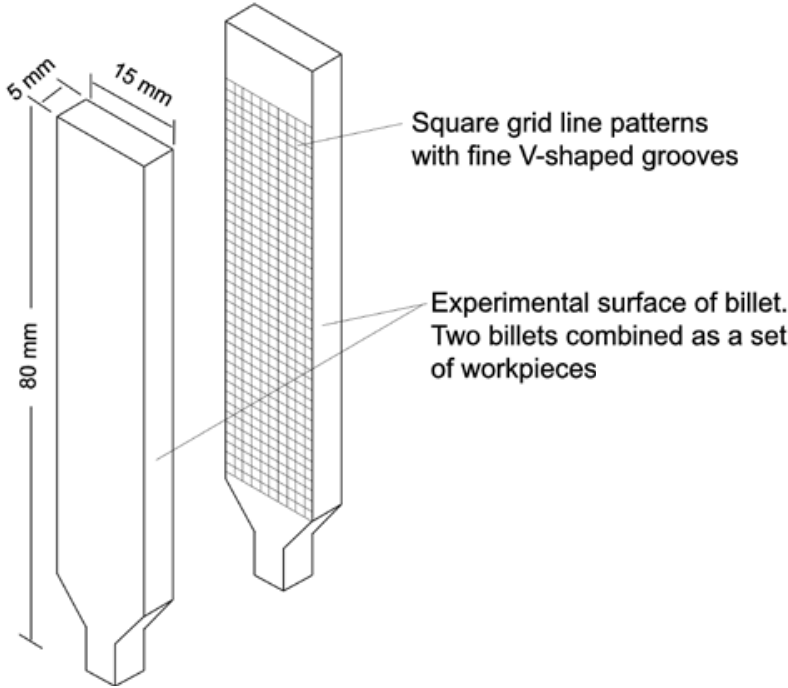

Figure 2. Schematic sketch of the billets (in $\mathrm{cm}$ ).

the oil under controlled conditions to low temperatures, followed by filtration of the crystals through membrane press (http://www.palmoilworld.org). RBD palm olein is the liquid fraction acquired from fractionation of palm oil. It is fully liquid at ambient temperature in warm climates. It is very different from RBD palm kernel oil which is semi-solid at ambient temperature and will turn into liquid when the temperature is in the range of $30^{\circ} \mathrm{C}-40^{\circ} \mathrm{C}$. The chemical and physical characteristics of RBD palm kernel oil and RBD palm olein are shown in Tables 5 and 6 . Previous research has shown that vegetable oil, which is environmental-friendly, degrades faster than mineral oil, and thus has significant increase in viscosity with aging condition. As highlighted by Wan Nik et al. (2007), vegetable-based palm oil could be a potentially useful substitute for mineral-based energy transport media such as hydraulic fluid.
Additive free paraffinic mineral oil VG95 and industrial oil daphnee were used as reference lubricants in order to find out the similarities between the two different types of lubricant, so as to see whether vegetable oil has the potential to be chosen as an alternative metal forming lubricant in the future.

All the values in Table 3 have been tested using viscometer. The heating process of $250 \mathrm{ml}$ lubricant was executed using a heater until the temperature reached $100^{\circ} \mathrm{C}$. Then, the heater was switched off to let the tested lubricant cool slowly to room temperature. All the data were recorded by a software according to the programmed database. One drop of lubricant (approximately $15 \mathrm{mg}$ ) was applied on the experimental surface of taper die before the experiment. The initial lubricant amount was predicted to create full film lubrication regime at the early stage of the extrusion process. ASTM D2270 was used for calculating the viscosity index (VI) from kinematic viscosity due to changes in the temperature of a petroleum product between $40^{\circ} \mathrm{C}$ and $100^{\circ} \mathrm{C}$.

\section{Experimental Procedure}

A hydraulic press machine was used to provide pressing force to the punch. During the extrusion process, the extrusion load and displacement displaced by the punch per unit time were recorded. A load cell was used to record extrusion load during the process, where a linear displacement velocity transducer (LVDT) was used to record the displacement displaced. Figure 3 shows the schematic sketch of the hydraulic press machine. The location of the load cell and LVDT are also shown in the same figure.

This study incorporated the use of computer to control the PID value. The analog input was taken from the system and modified to the signals,

TABLE 3. MECHANICAL PROPERTIES OF TESTING LUBRICANTS

\begin{tabular}{|c|c|c|c|c|c|}
\hline \multirow{2}{*}{\multicolumn{2}{|c|}{ Mechanical properties }} & \multicolumn{2}{|c|}{ Renewable } & \multicolumn{2}{|c|}{ Non-renewable } \\
\hline & & $\begin{array}{l}\text { RBD palm } \\
\text { kernel oil }\end{array}$ & $\begin{array}{l}\text { RBD palm } \\
\text { olein }\end{array}$ & $\begin{array}{c}\text { Industrial oil } \\
\text { daphnee }\end{array}$ & $\begin{array}{l}\text { Mineral oil } \\
\text { VG95 }\end{array}$ \\
\hline \multicolumn{2}{|c|}{ Relative density, $(\rho)$} & 0.86 & 0.85 & 0.90 & 0.86 \\
\hline \multicolumn{2}{|c|}{ Viscosity index } & 245 & 255 & 272 & 368 \\
\hline \multirow{2}{*}{$\begin{array}{c}\text { Kinematic } \\
\text { Viscosity, } \mathrm{mm}^{2} \\
\mathrm{~s}^{-1}\end{array}$} & $40^{\circ} \mathrm{C}$ & 31.32 & 35.78 & 42.05 & 71.75 \\
\hline & $100^{\circ} \mathrm{C}$ & 8.01 & 9.22 & 11.20 & 13.4 \\
\hline
\end{tabular}

Note: RBD - refined, bleached, deodorised. 


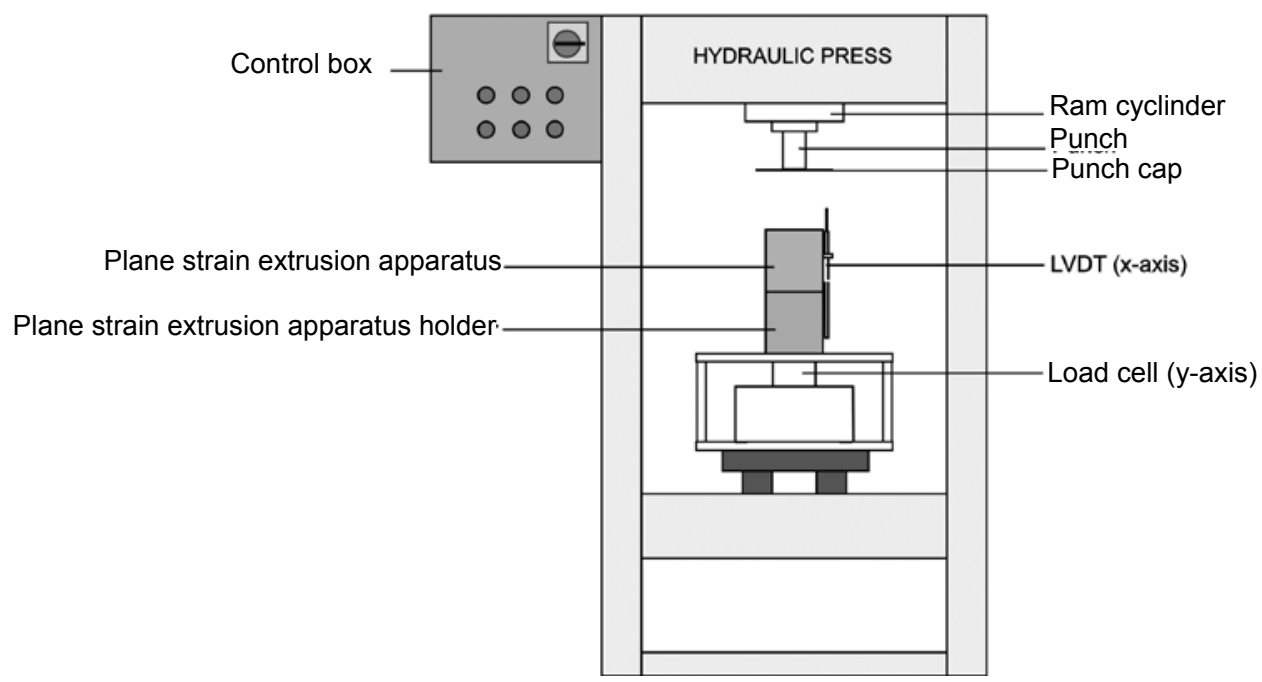

Note: LVDT - linear displacement velocity transducer.

Figure 3. Schematic sketch of the hydraulic press machine.

according to proportional, integral and derivative and the output was produced based on PID terms. The main hardware circuit of the study is the computer, analog to digital converter, digital to analog converter and the servo motor.

\section{RESULTS AND DISCUSSION}

\section{Extrusion Load}

The extrusion load-piston stroke curves are shown in Figure 4. The extrusion load reached a constant level during the process and the extrusion process became a steady state condition at a piston stroke $15 \mathrm{~mm}$ onwards. As piston stroke reached $35 \mathrm{~mm}$, the extrusion value for RBD palm kernel oil, RBD palm olein, daphnee and VG95 were recorded as $92.11 \mathrm{kN}, 86.00 \mathrm{kN}, 71.00 \mathrm{kN}$ and 49.35 $\mathrm{kN}$, respectively. All the curves show a reduction in extrusion load once the maximum load is reached. This trend may be due to the fact that the frictional force decreases linearly once the maximum load is reached, as proposed by Noorani et al. (2005).

From the graph, the usage of mineral oils require lower extrusion load compared to palm oil-based lubricants. The maximum load curve observed when RBD palm olein was used as lubricant is almost similar to the curve observed when daphnee was used as lubricant in the extrusion process. The similar trend obtained for the two curves can be explained by comparing their viscosity at room temperature, which is very close to each other, as shown in Table 4. Therefore their lubricity during the extrusion is expected to be similar. Liliang et al. (2012) said that a lubricant is suitable to be applied on contact area during the extrusion process if the lubricant used can minimise the extrusion load to a reasonable range.

The VG95 showed the lowest extrusion load when compared to other tested lubricants. In addition, the VI value was also lower because the lubricant was thicker and more concentrated. Due to these physical conditions, the use of VG95 resulted to less friction and less extrusion load during the extrusion process. Therefore, a lesser metal-to-metal

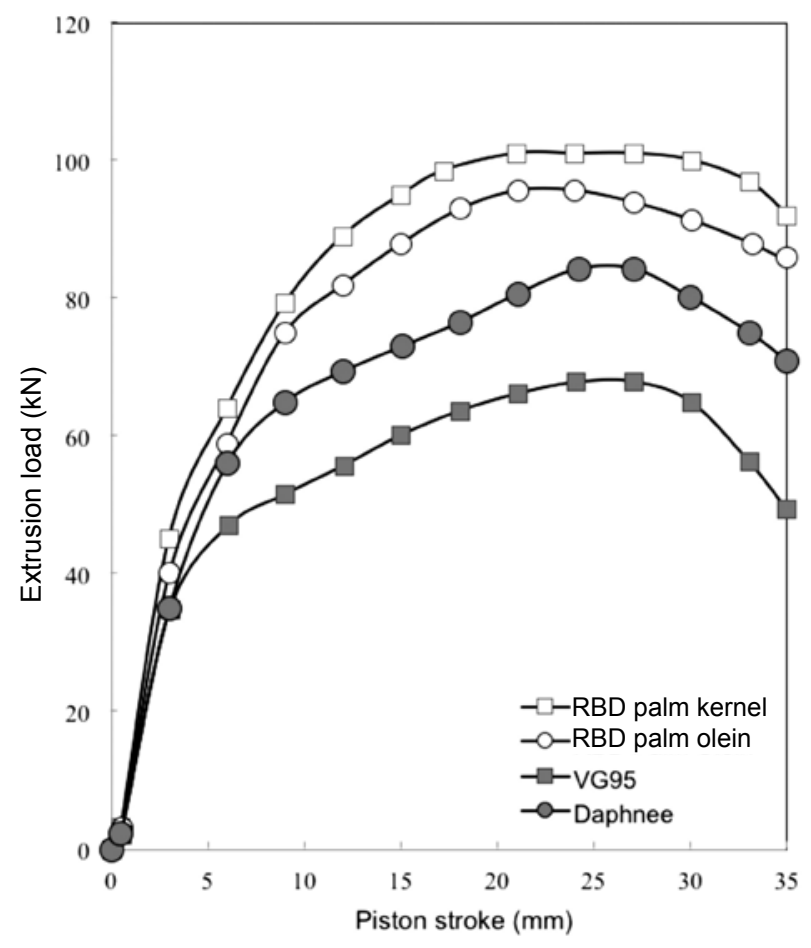

Note: RBD - refined, bleached, deodorised.

Figure 4. Extrusion load-piston stroke curves. 
TABLE 4. MAXIMUM LOAD OF TESTING LUBRICANTS VERSUS KINEMATIC VISCOSITY (ambient temperature)

\begin{tabular}{lcc}
\hline Testing lubricant & $\begin{array}{c}\text { Maximum } \\
\text { load (kN) }\end{array}$ & $\begin{array}{c}\text { Kinematic viscosity } \\
\left(\text { room } \mathbf{~}=\mathbf{2 7}^{\circ} \mathbf{C}\right), \mathbf{~ m m}^{\mathbf{2}} \mathbf{~ s}^{-1}\end{array}$ \\
\hline RBD palm kernel oil & 101.00 & 46.14 \\
RBD palm olein & 95.72 & 51.57 \\
VG95 & 67.64 & 249.95 \\
Daphnee & 84.33 & 51.57 \\
\hline
\end{tabular}

Note: RBD - refined, bleached, deodorised.

contact between billet and taper die was observed (Caminaga et al., 2006).

RBD palm kernel oil seemed to have more contact with sliding surface and it is proven that when more metal-to-metal contact occurs, the process needs more energy to shear the material and increase extrusion load. The finding is consistent with findings of past studies by Hafis et al. (2011; 2013), which found that extrusion load increases with coefficient of friction, either by experimental and finite element (FE) analyses.

As vegetable oil-based lubricant, RBD palm olein is preferable to mineral-based lubricants for metal forming process, particularly the cold extrusion process. This is consistent with the finding by Syahrullail et al. $(2009 ; 2012)$ in which low extrusion load of palm olein is comparable to metal forming lubricant. It was due to the composition of oleic acid that would help in reducing sliding friction (Chiong et al., 2012).

\section{Surface Roughness}

The distribution of arithmetic mean surface roughness, $R a$ on the product area of experimental surface billet (sliding plane) was measured with a surface profiler device. Product area is the region of the billet which is extruded from the taper die bearing. The measurement direction is perpendicular to the extrusion direction. The distribution of arithmetic mean surface roughness, $R a$ is shown in Figure 5.

Physically, RBD palm kernel oil was the least viscous lubricant among all the four lubricants and

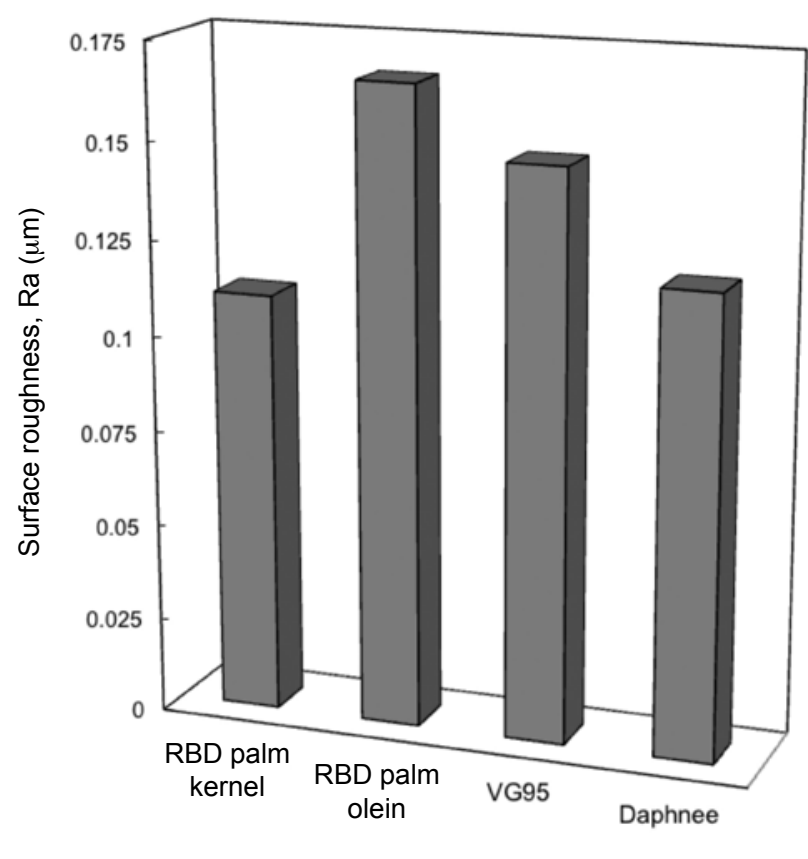

Note: RBD - refined, bleached, deodorised.

Figure 5. Arithmetic mean surface roughness, Ra at product area of extruded billets.

TABLE 5. CHEMICAL CHARACTERISTICS OF PALM KERNEL OIL AND REFINED, BLEACHED, DEODORISED (RBD) PALM OLEIN

\begin{tabular}{lcc}
\hline \multirow{2}{*}{ Characteristics } & \multicolumn{2}{c}{ Range } \\
\cline { 2 - 3 } & RBD palm kernel oil & RBD palm olein \\
\hline Iodine value (Wijs) & 16.2 to 19.2 & 56.0 to 59.1 \\
Saponification value, (mg KOH) & 243 to 249 & 194 to 202 \\
Unsaponification matter (\%), by weight & 0.1 to 0.8 & 0.3 to 1.30 \\
Fatty acid composition (wt\%) as methyl esters & & \\
C6:0 & 0.1 to 0.5 & - \\
C8:0 & 3.4 to 5.9 & - \\
C10:0 & 3.3 to 4.4 & - \\
C12:0 & 46.3 to 51.1 & 0.2 to 0.4 \\
C14:0 & 14.3 to 16.8 & 0.9 to 1.2 \\
C16:0 & 6.5 to 8.9 & 38.2 to 42.9 \\
C18:0 & 1.6 to 2.6 & 3.7 to 4.8 \\
C18:1 & 13.2 to 16.4 & 39.8 to 43.9 \\
C18:2 & 2.2 to 3.4 & 10.4 to 12.7 \\
Others & Trace to 0.9 & - \\
\hline
\end{tabular}

Source: Tan (1986). 
TABLE 6. PHYSICAL CHARACTERISTICS OF PALM KERNEL OIL AND REFINED, BLEACHED, DEODORISED (RBD) PALM OLEIN

\begin{tabular}{lcc}
\hline \multirow{2}{*}{ Characteristics } & \multicolumn{2}{c}{ Range } \\
\cline { 2 - 3 } & RBD palm kernel oil & RBD palm olein \\
\hline Refractive index & $\mathrm{nD} 30^{\circ} \mathrm{C}: 16.2$ to 19.2 & $\mathrm{nD} 40^{\circ} \mathrm{C}: 1.4589$ to 1.492 \\
Slip melting point $\left({ }^{\circ} \mathrm{C}\right)$ & 25.9 to 25.8 & 19.2 to 23.6 \\
Solid fat content by NMR $(\%)$ & & \\
$5^{\circ} \mathrm{C}$ & 68.0 to 76.8 & - \\
$10^{\circ} \mathrm{C}$ & 60.1 to 71.2 & - \\
$15^{\circ} \mathrm{C}$ & 50.5 to 60.0 & - \\
$20^{\circ} \mathrm{C}$ & 34.2 to 45.5 & - \\
$25^{\circ} \mathrm{C}$ & 10.2 to 21.5 & - \\
$30^{\circ} \mathrm{C}$ & $\mathrm{Nil}$ & 500 to 1200 \\
Total carotenoids as $\left(\beta\right.$-carotene), $\left(\mathrm{mg} \mathrm{kg}^{-1}\right)$ & - & \\
\hline
\end{tabular}

Source: Tan (1986).

has a high possibility to supply the lubricant from undeformed area to product area. It was different from RBD palm olein, VG95 and daphnee in which these lubricants tended to stay on the surface of sliding contact area due to their high concentrated physical attribute. The decreasing phenomenon of roughness in this region may be due to the highest contact pressure occurring at this region, as proposed by Tiernan et al. (2005).

Nevertheless, there was no significant difference in the surface roughness, as the results vary in the range between 0.1 and 0.25 micron. Charge couple device (CCD) camera was used to capture the images with a magnification of 200 and from the observation as illustrated in Figure 6, it was found that no severe wear has occurred. It also shows the image of undeformation area, a region of the billet where the cross-sectional area did not undergo any changes in size, or not being affected by the extrusion process.

\section{Relative Sliding Velocity}

The velocity component of the billets sliding on the taper die's surface was obtained from data tracing and calculated using visioplasticity method. Visioplasticity method is used for getting steadystate streamlines by using coordinate measuring machines to obtain data, which were then analysed by self-programmed visioplasticity database. The visioplasticity techniques permitted the attainment of steady-state streamlines and some data were processed to yield velocities, strain rates and finite strain for extrusion problems (Thomsen, 1964). The measurement distance starts from product area $(0 \mathrm{~mm})$, deformation area $(6-10 \mathrm{~mm})$ until the undeformation area $(14 \mathrm{~mm})$, which is represented by the $x$-axis.

The VG95 showed the highest relative velocity value at product area and deformation area. At

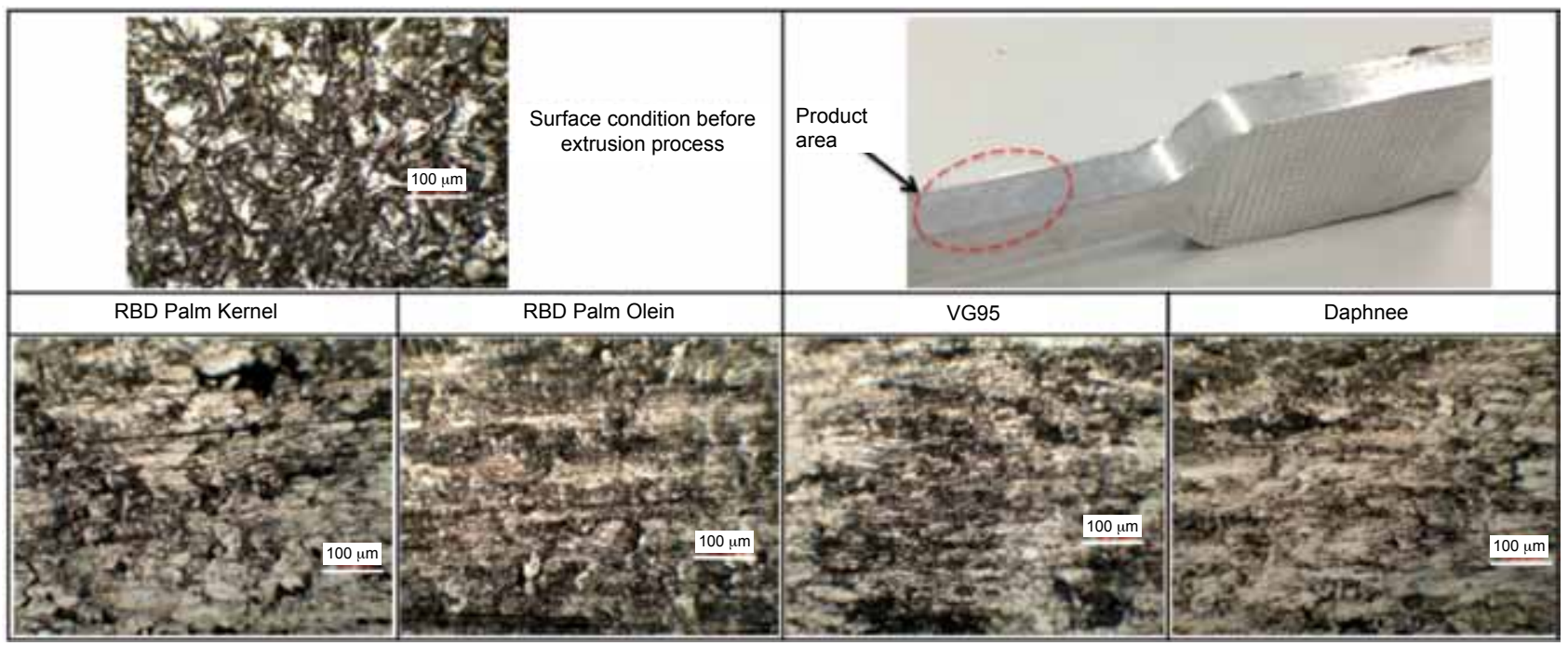

Note: RBD - refined, bleached, deodorised.

Figure 6. Change couple device (CCD) image at product area of extruded billets. 
deformation area, the value of the relative velocity was almost the same as that for RBD palm kernel oil and RBD palm olein. The trends had slightly changed where the value of relative velocity for daphnee became higher than RBD palm kernel when the sliding process reached product area.

Lesser load and friction will result in higher velocity of sliding action. By considering at product area, as shown in Figure 7, RBD palm olein tended to have a higher sliding velocity compared to RBD palm kernel oil. This is in line with what has been discussed on extrusion load earlier on, in which the extrusion process using RBD palm olein as a lubricant required more velocity to slide during deformation process. It is because less metal-tometal contact between billet and taper die led to low extrusion load usage and low friction effect (Syahrullail et al., 2011).

\section{Effective Strain}

Figure 8 shows the effective strain, $\varepsilon$ for the testing lubricant, where result was calculated by using visioplactisity method to map out the distribution of stress and strain rate. The variation of effective strain with respect to distance from the centre to periphery of the billet in the axial direction was clearly visualised. As mentioned earlier, the measurement distance also starts from product area $(0 \mathrm{~mm})$, deformation area $(6-10 \mathrm{~mm})$ until the

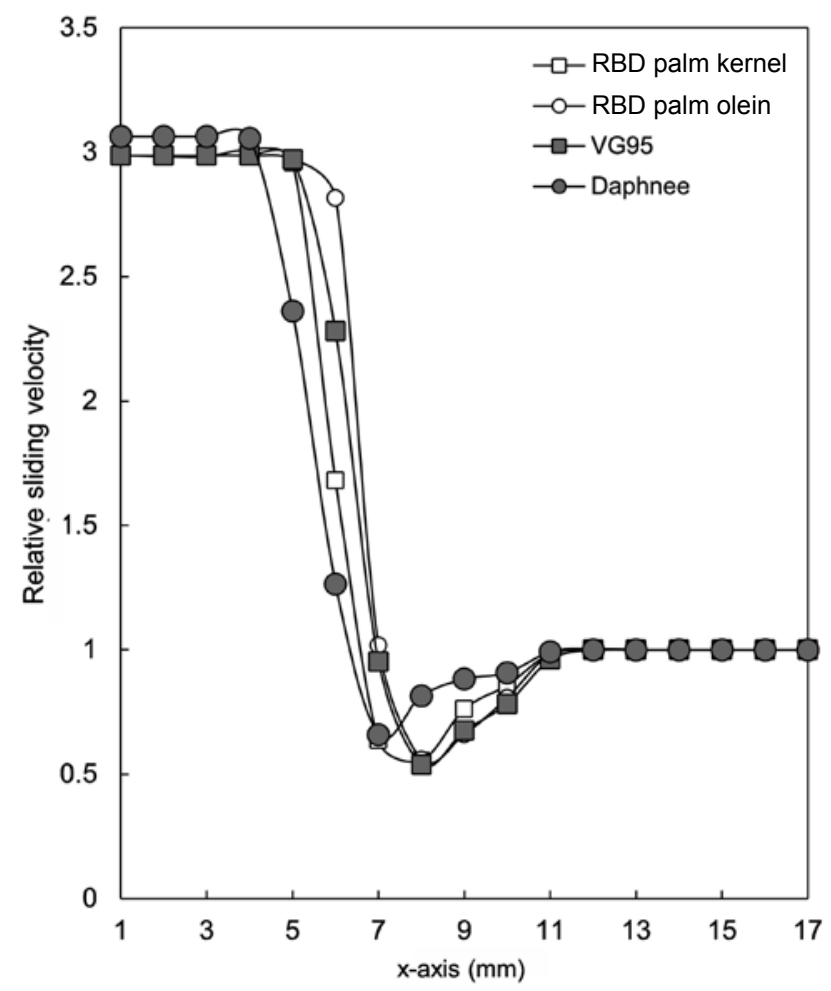

Note: RBD - refined, bleached, deodorised.

Figure 7. Resultant sliding velocity of extruded billets.

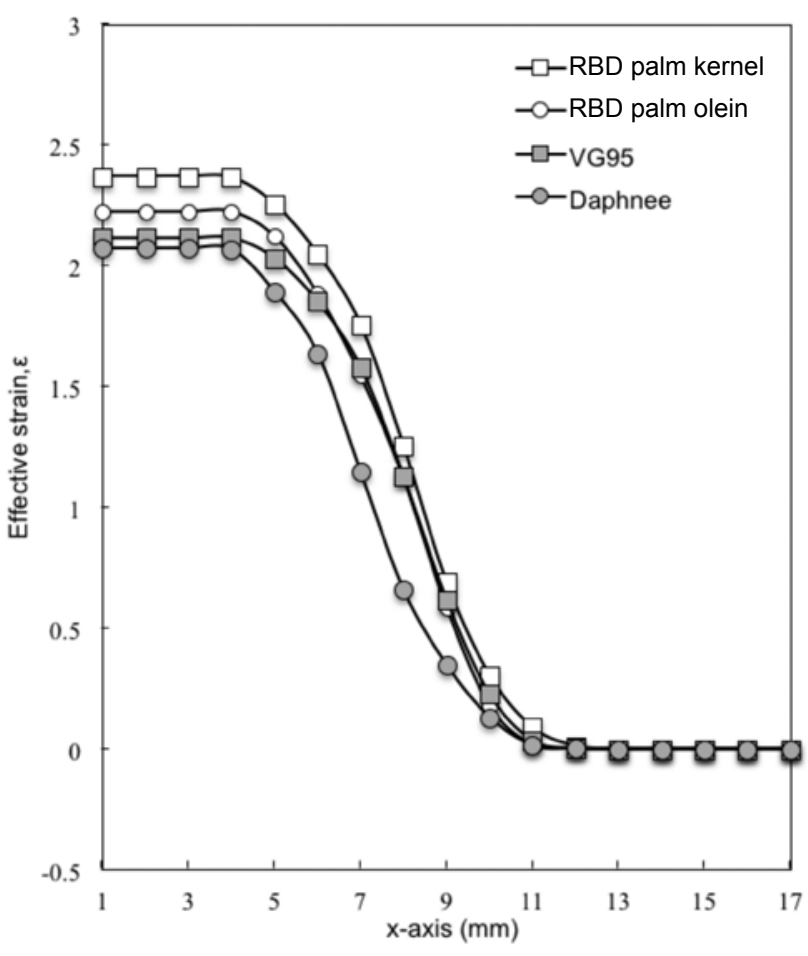

Note: RBD - refined, bleached, deodorised.

Figure 8. Effective strain of extruded billets.

undeformation area $(14 \mathrm{~mm})$, which is represented by the $\mathrm{x}$-axis.

Undeformation area showed no difference among each tested lubricants as the billet just started to slide. While in deformation area, the effective strain distribution extrusion of RBD palm kernel oil had higher values than RBD palm olein, followed by VG95 and daphnee. RBD palm kernel oil showed a slight increase in effective strain distributions compared to other tested lubricants. As mentioned in the previous analysis, RBD palm kernel oil has higher friction resulting in lower sliding velocity as compared to RBD palm olein. Due to that, RBD palm kernel oil elongation rate was 0.5 less than that of RBD palm olein. From the experiment conducted by Ganesh et al. (2008), it was found that the higher the liquidity of a lubricant, the greater is its hold ability during the operation. It is in line with this experiment where RBD palm kernel oil viscosity's value was less than the viscosity value of RBD palm olein.

\section{Metal Flow Pattern}

It is important to study the behaviour of the billet's metal flow extruded in this experiment in order to add value, yet strengthen the existing findings. Therefore, the horizontal flow lines of extruded billet were compared by analysing the flow line trend for each testing lubricant.

Flow line is used to study the metal flow during the extrusion. During the extrusion process, the 
magnitude of the frictional force affects the metal flow significantly. The area where frictional force is lower will flow faster than those with higher frictional force (Liliang et al., 2012). Therefore, the grid lines on the billet after the extrusion would look like wave profiles that are travelling toward the die. This is because the fictional force, which was created between the billet and taper die contact, was dragging the side of billet from moving, causing the metal flow faster in the middle part of the billet. The higher the fictional force, the bigger the distortion. According to Solomon and Solomon (2010), for a cylinder shape extrusion, the most deformed metal layer after the extrusion is the layer located between the outer surface and the half of the radius.

There are a total of 17 horizontal lines drawn on billet, as shown in Figure 9. The observation flow line covered the first and last line located at the sliding surface area. As plotted in Figure 10, RBD palm kernel oil created a high friction between tool and the billet surface, and it may cause the billet to deform more than usual during the extrusion process. By comparing this finding with sliding velocity's result, it is therefore proven that RBD palm kernel

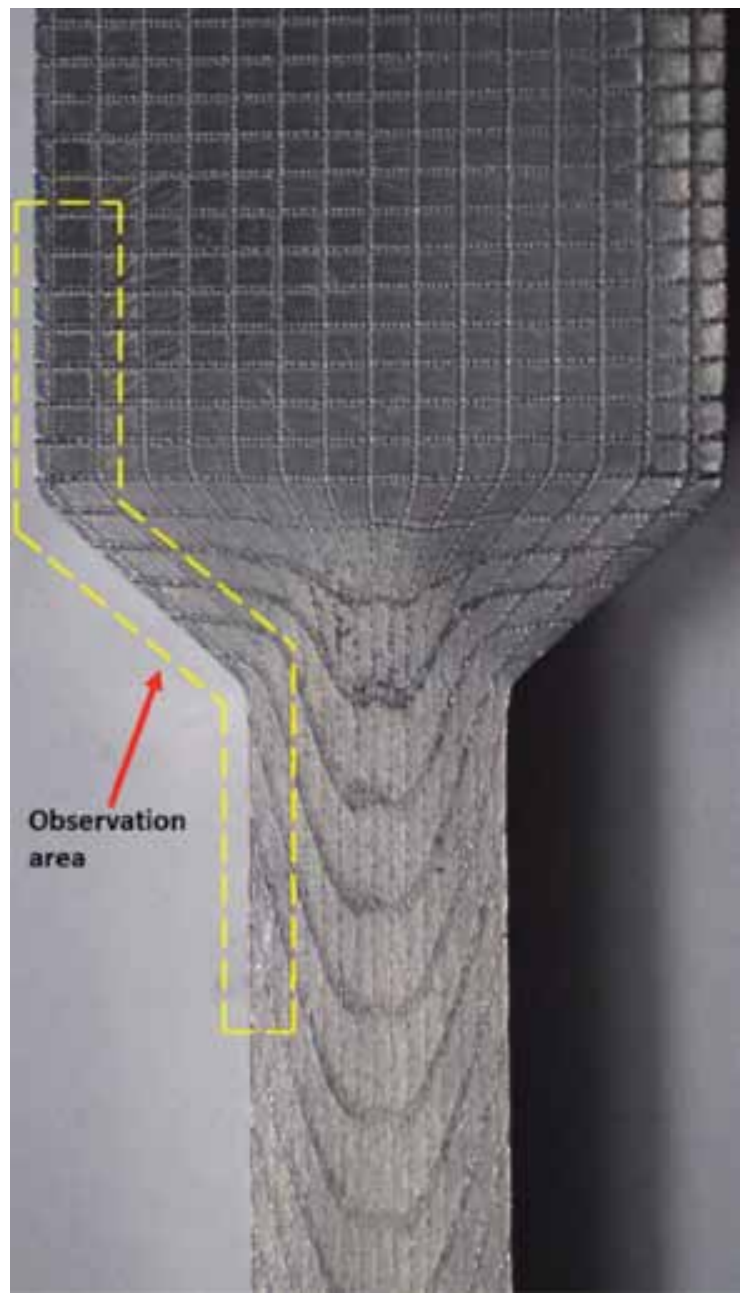

Figure 9. Observation area of metal flow pattern.

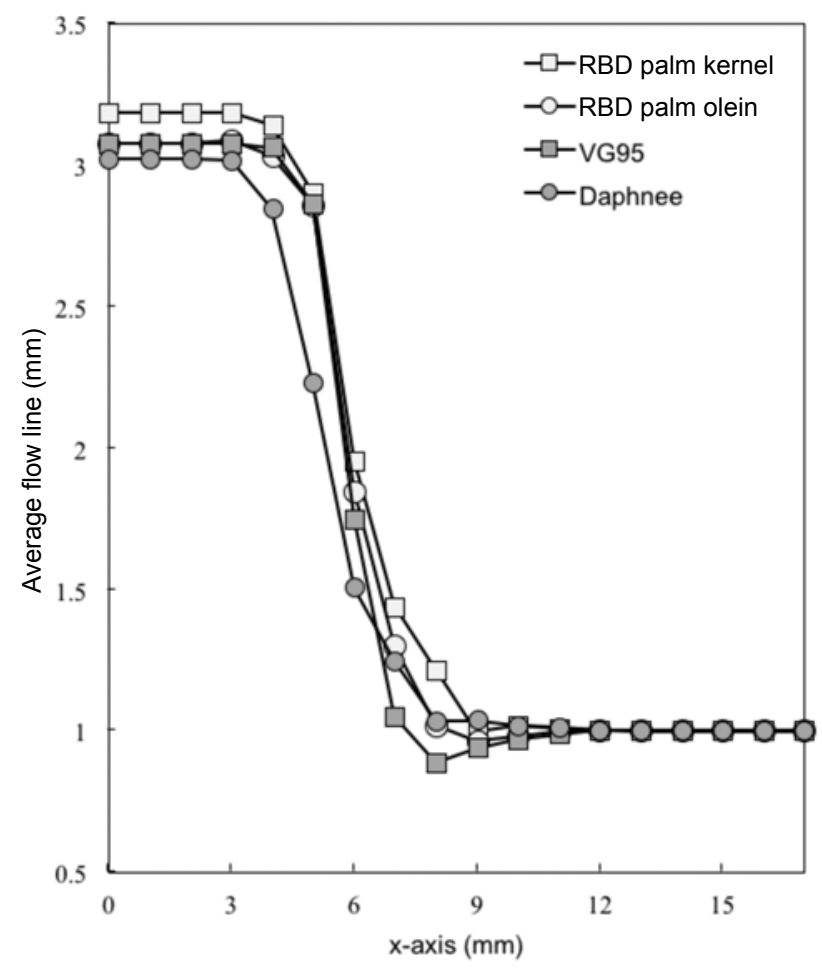

Note: RBD - refined, bleached, deodorised.

Figure 10. Flow line observation.

oil has more metal-to-metal contact as the result was significant compared to other lubricants.

According to Mariana et al. (2012), the metal flow pattern in extrusion depend on the local friction conditions and dies geometric shape. In other words, since the taper die used for all experiments was the same, there was no influence of metal flow pattern due to difference in die shape. Two types of frictions were developed during the extrusion process. They were sticking friction at the container surface and shear strength friction within the material layers itself, as proposed by Qamar et al. (2009). He explained that the difference in metal flow pattern during extrusion is due to the dominant friction during the extrusion process.

\section{CONCLUSION}

The main purpose of this study is to find alternatives to mineral-based lubricant for metal forming process. A study was successfully conducted with a cold work plane strain extrusion process on A1100 pure aluminum billet. The alternative lubricant was chosen from the two types of palm oil-based lubricant, RBD palm kernel oil and RBD palm olein. The results showed that due to high viscosity, the renewable lubricant tends to have similar attributes to the recommended non-renewable lubricant, in terms of its lesser extrusion load and friction 
Generally, extrusion using mineral-based lubricants requires lower maximum extrusion load compared with plant-based lubricants. However, the lubricity of the RBD palm olein is comparable to daphnee (commercialised lubricant in industry). Therefore, RBD palm olein is likely to replace daphnee as the commercial lubricant in metal forming processes, as far as its required maximum load is concerned.

There is no significant difference in surface roughness of the extruded product by mineral oilbased lubricant and plant-based lubricants. Both mineral-based and plant-based lubricants can produce products which have surface roughness, i.e. $0.2 \mu \mathrm{m}$. Thus, there is no obvious difference at surface quality from surface roughness findings and observation of the product area surface.

\section{ACKNOWLEDGEMENT}

The authors wish to thank the Faculty of Mechanical Engineering at the Universiti Teknologi Malaysia for their support and cooperation during this study. The authors also wish to thank the Research Management Centre (RMC) for the research university grant (GUP-09) from the Universiti Teknologi Malaysia, Fundamental Research Grant Scheme (FRGS-4F610) and E-Science grant from the Ministry of Education of Malaysia for their financial support.

\section{REFERENCES}

ANDREAS, W (2001). Lubricants based on renewable resources-an environmental compatible alternative to mineral oil products. Chemosphere, 43: 89-98. http: / / www.ncbi.nlm.nih.gov / pubmed / 11233830

BABATUNDE, L A and MICHAEL, B A (2008). Evaluations of vegetable oil-based as lubricants for metal forming processes. Industrial Lubrication Tribology, 60(5): 242-248. http:/ / www.researchgate. net/ publication / 233699505_Evaluations_of_ vegetable_oil-based_as_lubricants_for_metalforming_processes

CAMINAGA, C; RAFAEL LOPIS DA, S I and SERGIO TONINI (2006). Alternative lubrication and lubricants for the cold extrusion of steel parts. J. Material Processing Technology, 179: 87-91. http:// www.sciencedirect.com/science / article / pii / S0924013606002172

CAMINAGA, C; OZANAN NEVES, F; FERNANDO, $C$ and TONINI, B S (2007). Study of alternative lubricants to the cold extrusion of steel shafts. J. Material Processing Technology, 182: 432 - 439. http:// www.sciencedirect.com/science/article/pii / S092401360600776X
CHIONG, I T; RAFIQ, A K M; AZLI, Y and SYAHRULLAIL, S (2012). Tribological behaviour of refined, bleached and deodorized palm olein in different loads using four-ball tribotester. Scientia Iranica, 19(6): 1487-1492. http: / / www.sciencedirect. com/science/article/pii/S1026309812002386

GANESH, N R; GOPAL, $\mathrm{M}$ and RAJADURAI, A (2008). Influence of friction in simple upsetting and prediction of hardness distribution in a cold forged product. J. Testing Evaluation, 36(4): 371-383. http:/ / www.researchgate.net/publication / 216681326 Influence_of_friction_in_simple_upsetting_and_ prediction_of_hardness_distribution_in_a_cold_ forged_product

GARIETY, M; GRACIOUS, N and TAYLAN, A (2007). Evaluation of new cold forging lubricants without zinc phosphate precoat. International J. Machine Tools \& Manufacture, 47: 673-681. http:// www.sciencedirect.com / science / article / pii / S0890695506001271

HAFIS, S M; SYAHRULLAIL, S; AMRAN, A and RIDZUAN, M J M (2011). The effect of paraffinic mineral oil lubrication in cold forward extrusion. International J. Integrated Engineering, 3: 28-31. http: / / www.researchgate.net/publication / 261027911_ The_Effect_of_Paraffinic_Mineral_Oil_Lubrication_ in_Cold_Forward_Extrusion

HAFIS, S M; RIDZUAN, M J M; FARAHANA, R N; AYOB, A and SYAHRULLAIL, S (2013). Paraffinic mineral oil lubrication for cold forward extrusion: Effect of lubricant quantity and friction. Tribology International, 60: 111-115. http: / / www.sciencedirect. com.ezproxy.psz.utm.my / science / article / pii / S0301679X12003349/pdfft?md5=0b8a2d248a3d630b 22a4e06c7605bd70\&pid=1-s2.0-S0301679X12003349main.pdf

HIROFUMI, Y; SHIGEYOSHI, T; TOSHIHUMI, N; TOSHIJI, N and NAOYOSHI, I (2002). Application of wheat flour lubricants to the press-forming process. J. Material Processing Technology, 125-126: 375-378. http:// www.sciencedirect.com/science / article/pii/S092401360200345X

HU, Z M and DEAN, T A (2000). A study of surface topography, friction and lubricants in metal forming. International J. Machine and Manufacture, 40: 1637-1649. http:/ / www.sciencedirect.com/science / article/pii/S0890695500000146

JANOSEC, M; SCHINDLER, V; VODAREK, V; PALAT, J; RUSZ, S; SUCHANEK, P; RUZICKA, $M$ and MISTECKY, E (2007). Microstructure and mechanical properties of cold rolled, annealed 
HSLA strip steels. Archives of Civil and Mechanical Engineering, 8(2): 29-38. http:// www.sciencedirect. com/science/ article/ pii/S1644966512602088

LILIANG, W; JIE, Z; JUREK, D and LAURENS, K (2012). Friction in aluminum extrusion - part 1: a review of friction testing techniques for aluminum extrusion. Tribology International, 56: 89 - 98. http:// www.sciencedirect.com / science / article / pii / S0301679X12000370

LOVELL, M; HIGGS, C F; DESHMUKH, P and MOBLEY, A (2006). Increasing formability in sheet metal stamping operations using environmentally friendly lubricants. J. Material Processing Technology, 177: 87-90. http://www.sciencedirect.com/ science?_ob=ArticleListURL\&_method=list\&_ArticleListID $=-667703045 \&$ \& sort $=$ r\&_st $=13 \&$ view $=\mathrm{c} \& \mathrm{~m}$ d5=a9066148dfd8c1b00d26d3f75130aa4c\&searchtyp $\mathrm{e}=\mathrm{a}$

MPOB (2014). http: / / bepi.mpob.gov.my, accessed on 14 April 2014.

MPOB (2011). http:/ / www.palmoilworld.org, accessed on 29 September 2015.

MARIANA, P; DAN, F and ADRIANA, N (2012). Experimental and numerical aspects regarding lead alloy plastic deformation. Méchanical Applied, 1: 71-83. http://www.researchgate.net/ publication / 265408909_EXPERIMENTAL_AND_ NUMERICAL_ASPECTS_REGARDING_LEAD_ ALLOY_PLASTIC_DEFORMATION

NOORANI-AZAD; BAKHSHI-JOOYBARI M; HOSSEINIPOUR, S J and GORJI, A (2005). Experimental and numerical study of optimal die profile in cold forward rod extrusion of aluminum. J. Materials Processing Technology, 164-165: 1572-1577. http:// www.sciencedirect.com / science / article / pii / S0924013605000403

QAMAR, S Z (2009). FEM study of extrusion complexity and dead metal zone. Archives of Material Science and Engineering. 36 (2): 110-117. http: / / www. archivesmse.org/vol36_2/3627.pdf

QUINCHIA, L A; DELGADO, MA; REDDYHOFF, T; GALLEGOS, C and SPIKES, H A (2014). Tribological studies of potential vegetable oil-based lubricants containing environmentally friendly viscosity modifiers. Tribology International, 69: 110-117. http: / / www.sciencedirect.com / science / article / pii / S0301679X13002971
SEROPE, K and STEVEN, R S (2010). Manufacturing Engineering and Technology. $6^{\text {th }}$ edition, Prentice Hall, Singapore.

SOLOMON, N and SOLOMON, I (2010). Effect of die shape on the metal flow pattern during direct extrusion process. Revista De Metalurgia, 46(5): 396-404. http: / / revistademetalurgia.revistas.csic. es / index.php / revistademetalurgia / article / viewFile/1131/1143

SYAHRULLAIL, S; AZWADI, C S $\mathrm{N}$ and SEAH, W B (2009). Plasticity analysis of pure aluminium extruded with an RBD palm olein lubricant. $J$. Applied Science, 9: 19. http://www.sciencedirect. com/science/ article/ pii/S0020740311000919

SYAHRULLAIL, S; AZWADI, C S N; ABDUL KADIR, M R and SHAFIE, N E A (2011). The effect of tool surface roughness in cold work extrusion. $J$. Applied Science, 11: 367-372. http:/ / scialert.net/ fullt ext/ ?doi=jas.2011.367.372\&org $=11$

SYAHRULLAIL, S; KAMITANI, S and NAKANISHI, $\mathrm{K}$ (2012). Experimental evaluation of refined, bleached, and deodorized palm olein and palm stearin in cold extrusion of aluminum A1050. Tribology Transactions, 55(2): 199-209. http:// scival-expert. utm.my / pubDetail.asp?t=pm\&id $=84861113805 \&$

TAN, B K (1986). The chemistry and composition of palm oil and palm kernel oil. Proc. of the Palm Oil Mill Engineers/Executives Training Course. p. 32-36. http:/ / www.worldcat.org/title/porimsurvey-197980-oleins-and-stearins-from-malaysianpalm-oil-chemical-and-physical-characteristics / oclc/82844644\&referer=brief_results

TIERNAN, P; HILLERY, M T; DRAGANNESCU, $B$ and GHEORGHE, M (2005). Modelling of cold extrusion with experimental verification. J. Material Processing Technology, 168: 360-366. http:/ / imechanica.org/files/an_0.pdf

THOMSEN, E G (1964). Visioplasticity. University of California Publication.

WAN NIK, W B; MALEQUE, M A; ANI, F N and MASJUKI, H H (2007). Experimental investigation on system performance using palm oil as hydraulic fluid. Industrial Lubrication and Tribology, 59(5): 200208. http: / / www.emeraldinsight.com.ezproxy.psz. utm.my/doi / pdfplus / 10.1108 / 00368790710776784 